HortSCIENCE 27(12):1291-1294. 1992.

\title{
Physiological Changes Associated with Development of Mealiness of Apple Fruit during Cool Storage
}

\author{
F.R. Harker and I.C. Hallett \\ Horticulture and Food Research Institute of New Zealand, Mount Albert \\ Research Centre, Private Bag 92169, Auckland, New Zealand
}

Additional index words. Malus domestica, texture, juiciness, maturity, tensile tests

\begin{abstract}
The relationships between cellular characteristics of cortical tissue from 'Braeburn' apple fruit (Malus domestica Borkh.) that had been harvested at two maturities and changes in texture that occurred during storage at $0 \mathrm{C}$ were studied. Tensile tests were used to measure adhesion between neighboring cells, and turgor pressure was manipulated to determine the pressures required to burst cells. Apples of advanced maturity became mealy during cool storage, while those of less advanced maturity did not. Mealiness was associated with low adhesion between neighboring cells, and a relatively high resistance to cell rupture.
\end{abstract}

Apples are characteristically crisp and juicy fruit, but during cool storage texture can deteriorate, resulting in soft, dry, mealy fruit. Mealiness in apples (the breakdown of flesh into small pieces in the mouth, which tend to be dry) particularly occurs in overmature apples that have been cool-stored (Fisher, 1943). Studies have related apple texture to cell wall structure (Ben-Arie et al., 1979) and the relative areas of cell-to-cell contact (Vincent, 1989). However, we found no study of those attributes of apple tissue that influ-

Received for publication 10 Feb. 1992. Accepted for publication 15 July 1992. The cost of publishing this paper was defrayed in part by the payment of page charges. Under postal regulations, this paper therefore must be hereby marked advertisement solely to indicate this fact. ence the way that cells rupture and release juice.

The ease with which cells in fruit tissue burst is probably related to the strength and elasticity of the cell wall and plasma membrane as well as to the strength of adhesion between neighboring cells. Adhesion might be expected to influence the way fruit tissue breaks when chewed by determining whether 1) the fruit tissue breaks into small fragments containing undamaged cells or 2) individual cells rupture when crushed, leaving a pulp of connecting cell wall material. Although there are no simple methods for measuring either cell adhesion or the elasticity of the cell wall and plasma membrane, we looked at some existing physiological and mechanical tests with the aim of identifying the relationship between these two factors. 
Table 1. Physiological characteristics of fruit harvested with green (low-maturity) or yellow (highmaturity) background colors. Valucs represent the means \pm SE determined from 20 fruit.

\begin{tabular}{lrr}
\hline & \multicolumn{1}{c}{ Maturity } & \multicolumn{1}{c}{ High } \\
\cline { 2 - 3 } Fruit maturity & \multicolumn{1}{c}{ Low } & $4.6 \pm 0.1$ \\
\hline Background color & $1.3 \pm 0.1$ & $14.9 \pm 4.9$ \\
Internal ethylene $\left(\mu / \cdot\right.$ liter $\left.^{-1}\right)$ & $0.7 \pm 0.2$ & $4.0 \pm 0.1$ \\
Starch pattern index & $2.9 \pm 0.3$ & $73.5+1.0$ \\
Flesh firmness $(\mathrm{N})$ & $75.5 \pm 1.0$ & $14.2 \pm 0.1$ \\
Soluble solids concn $(\%)$ & $10.5 \pm 0.2$ & \\
\hline
\end{tabular}

$z_{1}=$ Green, $6=$ yellow.

$y_{0}=$ No starch hydrolysis; $6=100 \%$ starch hydrolysis.

Table 2. Changes in fruit texture during cool storage. Texture was assessed using tensile or compressive tests. Tensile and compressive forces were divided by the area over which the force was applied ( 0.48 and $0.97 \mathrm{~cm}^{2}$ for tensile and compressive tests, respectively) to allow direct comparison between the methods of measuring texture. Values represent means \pm SE, as determined from duplicate measurements on eight fruit.

\begin{tabular}{|c|c|c|c|c|c|c|}
\hline \multirow[b]{2}{*}{ Maturity } & \multicolumn{3}{|c|}{ Tensile strength } & \multicolumn{3}{|c|}{ Resistance to compression } \\
\hline & $\begin{array}{c}\text { At } \\
\text { harvest } \\
\left(\mathrm{N} / \mathrm{cm}^{2}\right)\end{array}$ & $\begin{array}{l}\text { 16-Week } \\
\text { storage } \\
\left(\mathrm{N} / \mathrm{cm}^{2}\right)\end{array}$ & $\begin{array}{l}\text { Loss } \\
(\%)\end{array}$ & $\begin{array}{c}\text { At } \\
\text { harvest } \\
\left(\mathrm{N} / \mathrm{cm}^{2}\right)\end{array}$ & $\begin{array}{c}\text { 16-Week } \\
\text { storage } \\
\left(\mathrm{N} / \mathrm{cm}^{2}\right)\end{array}$ & $\begin{array}{l}\text { Loss } \\
(\%)\end{array}$ \\
\hline Low & $34.3 \pm 1.4$ & $14.2 \pm 0.7$ & 58 & $84.0 \pm 1.4$ & $69.5 \pm 1.4$ & 17 \\
\hline High & $30.3 \pm 1.8$ & $7.8^{z} \pm 0.7$ & 74 & $76.9 \pm 1.7$ & $63.8^{2} \pm 1.4$ & 17 \\
\hline \multirow{2}{*}{$\begin{array}{l}\text { Difference in } \\
\text { texture }(\%)\end{array}$} & & & & & & \\
\hline & 12 & 45 & -- & 8 & 8 & $\cdots$ \\
\hline
\end{tabular}

${ }^{2}$ Mealy fruit.

Table 3. Cellular characteristics of tissue from apples harvested at low and high maturities, then stored for 16 weeks at $O C$. Air space and soluble solids levels are presented as means \pm SE for a minimum of eight fruit, cell wall yields relate to a bulked sample from 10 apples, and turgor pressures at cell rupture are calculated from concentrations of mannitol at cell rupture (Fig. 1) and the osmotic potential of the juice as estimated from the soluble solids concentration (SSC).

\begin{tabular}{|c|c|c|c|c|}
\hline \multirow[b]{2}{*}{ Maturity at harvest } & \multicolumn{2}{|c|}{ At harvest } & \multicolumn{2}{|c|}{ 16-Week storage } \\
\hline & Low & High & Low & $\mathrm{High}^{2}$ \\
\hline $\begin{array}{l}\text { Cell wall extracted } \\
\text { (g dry wt/kg fresh wt tissue) }\end{array}$ & 17.5 & 22.7 & 16.2 & 19.5 \\
\hline Airspace (\%) & $15.7 \pm 0.2$ & $17.4 \pm 0.2$ & $16.8 \pm 0.2$ & $18.1 \pm 0.3$ \\
\hline $\operatorname{SSC}(\%)$ & $10.5 \pm 0.2$ & $14.2 \pm 0.1$ & $11.6 \pm 0.3$ & $14.4 \pm 0.1$ \\
\hline Mannitol conen at cell rupture (molal) & 0.2 & 0.3 & 0.4 & 0.3 \\
\hline Osmotic potential ${ }^{\mathrm{A}}(\mathrm{MPa})$ & -1.33 & -1.80 & -1.46 & -1.82 \\
\hline Water potential ${ }^{\mathrm{B}}(\mathrm{MPa})$ & -0.46 & -0.69 & -0.92 & -0.69 \\
\hline Turgor at cell rupture ${ }^{\mathrm{B}-\mathrm{A}}(\mathrm{MPa})$ & 0.87 & 1.11 & 0.54 & 1.13 \\
\hline
\end{tabular}

${ }^{z}$ Mealy fruit.

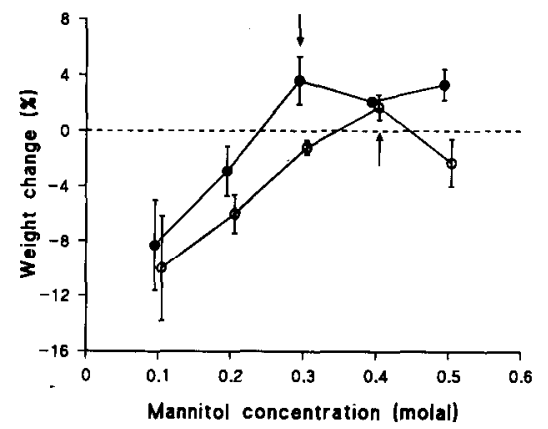

Fig. 1. Changes in the weight of apple fruit cortical disks following incubation for $3 \mathrm{~h}$ in mannitol solutions of varying osmotic potential. Values represent mean weight changes \pm SE for duplicate 1-g samples of disks cut from low$(O)$ and high- (-) maturity fruit after 16 weeks of storage at $\mathrm{OC}$. Arrows indicate the lowest concentration of mannitol that does not result in cell rupture. Weight changes to the left of the arrows were due to losses of cell contents, while weight changes to the right of the arrows were due to uptake and loss of water from intact cells. harvested after the closure of the commercial harvest period to ensure incidence of mealiness, and apples with green background color were harvested to ensure some fruit remained nonmealy. Earlier studies indicated that overmature fruit do become mealy during cool storage, while those of less advanced maturity do not (Fisher, 1943). Having selected fruit of two maturities, a range of cellular and physiological approaches was used to follow textural changes in fruit during cool storage, with the aim of identifying those characteristics of cells most closely associated with mealiness.

The apples were harvested from trees growing in the HortResearch Orchard in Havelock North, New Zealand, on 26 Apr. 1990 and divided into two groups according to background color. Fruit with a green background were classified as lower maturity (low) and fruit with a yellow background were classified as advanced maturity (high). Subsamples of 20 fruit from each maturity group were assessed for background color, internal ethylene concentration, starch pattern index, flesh firmness, and soluble solids concentration (SSC). Background color was determined by the Echelle colorimetrique de la Golden Delicious (Centre Francais du Commerce Exterieur) modified so that the greenest fruit scored 1, and the yellowest fruit scored 6. Samples of gas $(1 \mathrm{ml})$ were taken from the core cavities and immediately analyzed for ethylene by gas chromatography. Fruit density was determined by weighing the fruit while they were floating in water and again while submerged, using the methods described by Hatfield and Knee (1988). This value, in conjunction with the specific gravity (SG) of juice extracted from cortical flesh using a garlic crusher, was used to calculate the air space in whole fruit using the following formula (Hatfield and Knee, 1988):

$$
\% \text { Air space }=1-\frac{\text { fruit density }}{\text { SG juice }} \times 100
$$

Flesh firmness was measured using an Effegi pressure tester (Effegi, Italy) (11.1-mm-diameter head) on opposite sides around the equator of each apple after the skin had been pared. The combined juice expressed from both sides of the apples during flesh firmness measurement was collected directly onto a hand-held refractometer (0\% to 20\%; Atago, Tokyo) to measure SSC. Each apple was cut through the equator, and the stem end was dipped for $30 \mathrm{sec}$ in iodine solution before assessment for starch hydrolysis using a starch pattern index chart where $0=$ no starch hydrolysis and $6=100 \%$ hydrolysis (Reid et al., 1982).

Cellular characteristics of cortical tissue from high- and low-maturity apples were determined at harvest and after 16 weeks storage at $0 \mathrm{C}$ using eight fruit per color category. For compression tests, flesh firmness was measured as described above. For tensile tests, a 10-mm-diameter cork borer was inserted radially and two plugs of cortical tissue were removed from the remaining quadrants around the equator of each apple. Each plug was 

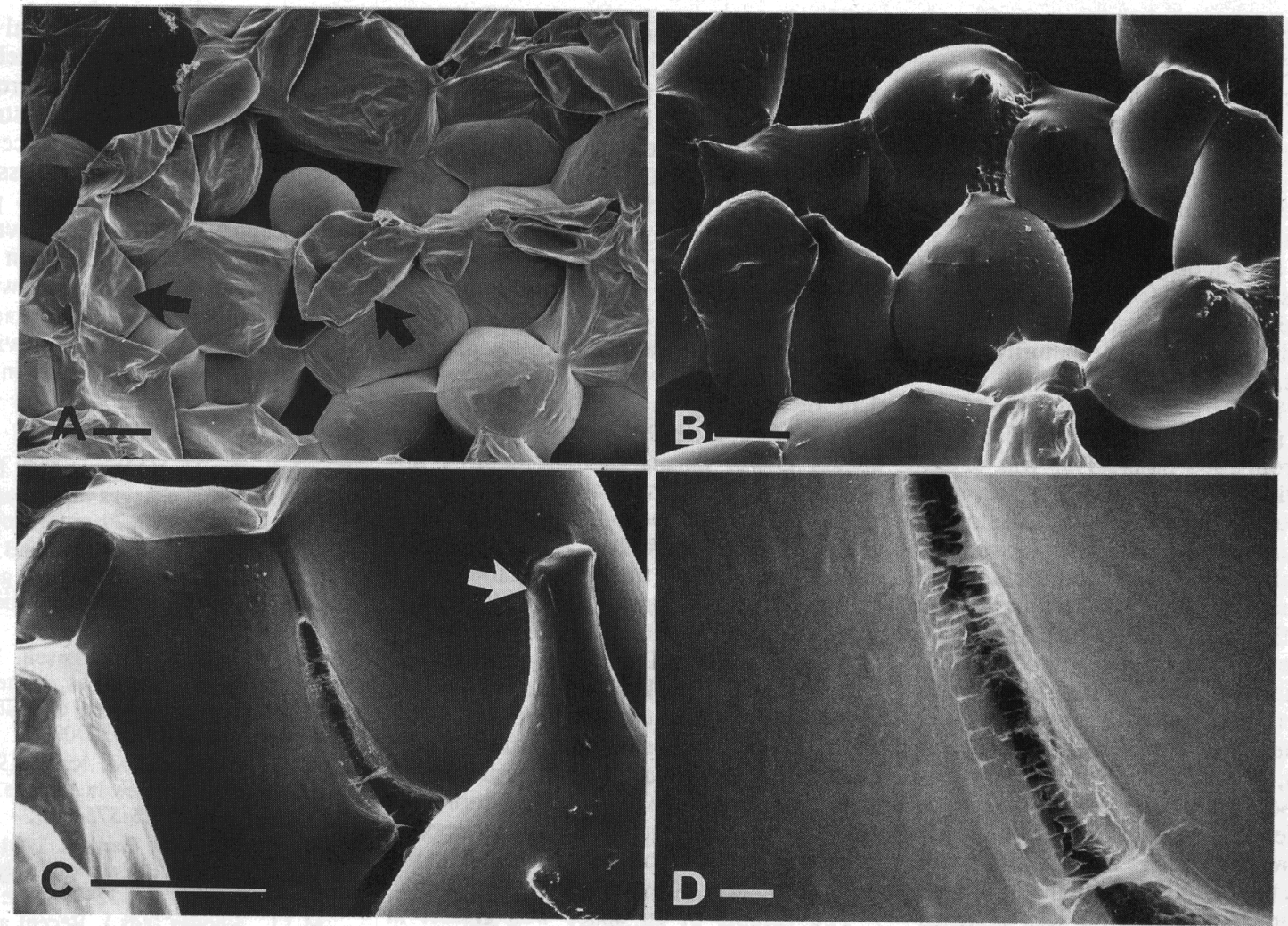

Fig. 2. Fracture surfaces of plugs of apple cortical tissue following tensile tests as observed using low-temperature scanning electron microscopy. Apples were stored for 16 weeks at $0 \mathrm{C}$ before application of tensile tests. (A) Cells at the fracture surface from nonmealy tissue showing collapsed cells (arrowed) that have apparently been ruptured and lost contents during the fracture process. (B-D) Cells from the fracture surface of mealy tissue. Cells show no collapse (B) but do show some distortions (arrowed) $(\mathbf{C})$ and tearing apart of cells in the region of the middle lamella (D). Scale bar $=0.1 \mathrm{~mm}(\mathbf{A}-\mathbf{C})$.
$10 \mathrm{~m}(\mathbf{D})$. Magnification is $\times 80$ (A), $\times 100$ (B), $\times 240$ (C), and $\times 725$ (D).

then cut into an H-shaped section as described by Stow (1989) using a preshaped cutter. The waist of the section was $5 \mathrm{~mm}$ in diameter. The tensile test was applied by inserting the section between two sets of claws of an Instron model 4301 materials testing machine (Instron, Canton, Mass.). The sets of claws moved apart at the rate of 2 $\mathrm{mm} \cdot \mathrm{min}^{-1}$, stretching the tissue section until it snapped across the waist. The force required for tissue failure was recorded, and this value was divided by the waist crosssectional area to give results as Newtons per square centimeter, allowing comparison between compression and tensile tests.

Following tensile tests, samples of fractured surfaces were viewed using low-temperature scanning electron microscopy. Tissue was frozen in liquid nitrogen slush and transferred under vacuum to the processing chamber of an EMSCOPE SP 2000 Sputter Cryo system (Emscope, U.K.). The surface ice was removed by etching the sample at - 80C for $10 \mathrm{~min}$ before sputter-coating with gold at a stage temperature of - $150 \mathrm{C}$. The samples were then transferred, under vacuum, for observation on a cold stage at a temperature lower than - 150C in a Philips scanning electron microscope (Philips, Eindhoven The Netherlands) at an accelerating voltage of $1.5 \mathrm{kV}$.

The turgor pressures required to rupture cells were determined on disks of cortical tissue (10 $\mathrm{mm}$ in diameter, $3 \mathrm{~mm}$ thick) cut from five apples. Disks were combined, then rinsed in deionized water $(30 \mathrm{sec})$ and blotted dry. Disks of $\approx 1 \mathrm{~g}$ were weighed to a precision of $\pm 0.001 \mathrm{~g}$ into duplicate $50-\mathrm{ml}$ flasks containing $20 \mathrm{ml}$ of $0.1,0.2,0.3,0.4$, or 0.5 molal mannitol with $0.5 \mathrm{~mm}$ mercaptobenzothiozole and $0.5 \mathrm{~mm} \mathrm{CaCl}_{2}$. The disks were incubated in these solutions for $3 \mathrm{~h}$ before being filtered, blotted, and reweighed. The lowest concentration of osmoticum below which cells started to burst was determined from plots of concentration against changes in disk weight (Fig. 1). The maximum increase in disk weight indicated uptake of water by osmosis, and cells burst when the disks were placed in lower concentrations of mannitol. The turgor pressure required to burst the cells was then estimated using the formula $\mathrm{P}=\psi-\pi$, where $\mathrm{P}$ is the turgor pressure, $\psi$ is the water potential at the point of bursting (estimated from graph), and $\pi$ is the osmotic potential of the cell sap. Osmotic potential of the apple cortical tissue was estimated from the SSC, assuming that soluble sugars were the main contributor to the osmotic potential and ignoring the effects of other solutes. The SSC was used in conjunction with the relationship between sugar concentrations (percent fructose) and solution potential (megaPascals). For example, we assumed that a SSC of $10 \%$ related to 10 $\mathrm{g}$ fructose in $100 \mathrm{ml}$ water, which is $\approx 0.55$ molal fructose. This molality relates to an osmotic potential of $-1.25 \mathrm{MPa}$ at $25 \mathrm{C}$ according to tables (Lang, 1967).

Cell walls were isolated to investigate the relationship between cell wall yield of the tissue and fruit texture. Fresh cortical tissue $(200 \mathrm{~g})$ from another 10 apples was homog enized in a solution containing $200 \mathrm{~g}$ phenol, $100 \mathrm{ml}$ glacial acetic acid, and $100 \mathrm{ml}$ deionized water. Cell walls were then isolated from the homogenate using the methods of Redgwell et al. (1992), and the cell wall yield was calculated as grams dry cell wall per kilogram fresh tissue.

Maturity assessments confirmed that selection of 'Braeburn' apples according to green and yellow background color separated the fruit into two maturity groups ( $\mathrm{Ta}$ ble 1). Changes in texture (Table 2) and cellular characteristics (Table 3, Fig. 1) occurred to different degrees in fruit of the two maturity groups during 16 weeks of cool storage. Informal tasting by one assessor indicated that while no apples were mealy at harvest, four out of 20 low- and 16 out of 20 high-maturity fruit were mealy after cool storage. This result is consistent with the findings of Fisher (1943), who also found that high-maturity apples became mealy during cool storage, while low-maturity apples did not.

Measurements of the tensile strength of fruit tissue indicated that cell adhesion de- 
creased $>50 \%$ during cool storage and that after 16 weeks of cool storage, there was a clear difference between the adhesion of cells from apples harvested at low or high maturity (Table 2). The relative changes in tensile strength were far larger than the changes in flesh firmness measured using a hand-held penetrometer. This difference suggests that tensile tests are not only more sensitive measures of flesh softening but also able to discriminate between cool-stored high-maturity (mealy) and cool-stored low-maturity (nonmealy) fruit.

Changes in the tensile strength of apple tissue were related to the way in which cells separated from each other. This was determined by viewing the fracture surface. Application of tensile tests following cool storage of low-maturity apples resulted in the rupture of individual cells at the fracture surface and the subsequent release of cell contents and collapse of the cell wall (Fig. 2A). However, when tensile tests were applied to cool-stored high-maturity fruit, neighboring cells were pulled apart, leaving undamaged cells exposed at the fracture surface (Fig. 2B). In some cases, the cells from these high-maturity fruit became considerably distorted, yet still remained intact (Fig. 2C). Cells immediately below the fracture surface often separated from their neighbors, so that a residue of middle lamella material was seen stretched between adjoining cells (Fig. 2D).

The results from tensile tests and observations of fracture surfaces suggested that, following storage, cells from low-maturity apples were more liable to rupture than cells from high-harvest-maturity apples. This conclusion was supported by estimates of the turgor pressure required to rupture cells, as well as measurements that suggested that cell walls were thicker and/or denser in high-maturity fruit.

At harvest, there was little difference in the turgor pressures at which cells from apples of either maturity ruptured (Table 3 ). However, after 16 weeks of cool storage, the pressures required to rupture cells from lowmaturity fruit had decreased $40 \%$, while there was no change in the pressure required to burst cells from high-maturity fruit (Table 3, Fig. 1).

The ease with which cells rupture is af- fected by the structural characteristics of both the cell wall and plasma membrane. Cell rupture occurs when the plasma membrane is stretched until it breaks. The cell wall, however, impedes the increases in protoplast volume during osmotic uptake of water, and cell wall elasticity will determine the extent that the plasma membrane is stretched. As such, the ease with which cells ruptured may be partly explained by the differences in amounts of cell wall extracted from the fruit tissue, as well as changes in cell wall composition. More wall was extracted from highthan low-maturity apples (Table 3 ). This result could indicate that the cell walls were thicker and/or denser in high-maturity apples, as long as the surface areas of the cell walls are equal in both high- and low-maturity fruit. However, it is more likely that the cell wall surface area was smaller in the high-maturity fruit, since they had more air space (Table 3), a characteristic that usually indicates smaller cell surface areas (Harker and Ferguson, 1988). Thus, the differences between cell wall thickness and/or density in apples of low and high maturity may be even greater than indicated by our results. Cell wall yields were lower following cool storage of both high- and low-maturity apples, indicating degradation of cell wall material during ripening (Knee and Bartley, 1981).

The volume of air space was greater in apples harvested at high than at low maturity, and although air space expanded during cool storage, this relative difference was maintained. Other studies (Hatfield and Knee, 1988; Vincent, 1989) have also demonstrated a relationship between large air space volumes and poor apple texture. Thus, it seems likely that high levels of air space are symptomatic of mealiness. The cause of these large air spaces and mealy texture is probably related to the degradation of the middle lamella and corresponding reduction in cell adhesion. The cells are then able to expand slightly and become more rounded, with the result that air spaces increase and cell contact areas decrease. This change in cell shape and cell expansion seems to be a turgor-driven process (Hatfield and Knee, 1988).

These findings suggest that, during cool storage, cells from high-maturity fruit tend to lose cell-to-cell adhesion but maintain cell wall strength, so that individual cells are difficult to rupture. In contrast, cells from lowmaturity fruit tend to maintain relatively high cell-to-cell adhesion, but the strength of the cell wall declines so that the cells are easily ruptured. During chewing, tissue from the high-maturity apples may be perceived as mealy because it breaks down into small clumps of undamaged cells. In comparison, cells from nonmealy apples, which are relatively strongly attached to each other and are relatively easy to rupture, will be crushed and release their contents during chewing.

\section{Literature Cited}

Ben-Arie, R., N. Kislev, and C. Frenkel. 1979. Ultrastructural changes in cell walls of ripening apple and pear fruit. Plant Physiol. 64:197-202.

Fisher, D.V. 1943. Mealiness and quality of Delicious apples as affected by growing conditions, maturity and storage techniques. Sci. Agr. 23:569-588.

Harker, F.R. and I.B. Ferguson. 1988. Calcium ion transport across discs of the cortical flesh of apple fruit in relation to fruit development. Physiol. Plant. 74:695-700.

Hatfield. S.G.S. and M. Knee. 1988. Effects of water-loss on apples in storage. Intl. J. Food Sci. \& Technol. 23:575-585.

Knee, M. and I.M. Bartley. 1981. Composition and metabolism of cell wall polysaccharides in ripening fruits, p. 132-148. In: J. Friend and M.J.C. Rhodes (eds.). Recent advances in the biochemistry of fruits and vegetables. Academic, London.

Lang, A.R.C. 1967. Osmotic coefficients and water potentials of sodium chloride solutions from 0 to $40^{\circ} \mathrm{C}$. Austral. J. Chem. 20:2017-2023.

Redgwell, R.J., L.D. Melton, and D.J. Brasch. 1992. Cell wall dissolution in ripening kiwifruit (Actinidia deliciosa) solubilisation of pectic polymers. Plant Physiol. 98:71-81.

Reid, M.S., C.A.S. Padfield, C.B. Watkins, and J.E. Harman. 1982. Starch iodine pattern as a maturity index for Granny Smith' apples 1 . Comparison with flesh firmness and soluble solids content. N.Z. J. Agr. Res. 25:239-241.

Simon, E.W. 1977. Leakage from fruit cells in water. J. Expt. Bot. 28:1147-1152.

Stow, J. 1989. The involvement of calcium ions in maintenance of apple fruit tissue structure. J. Expt. Bot. 40:1053-1057.

Vincent, J.F.V. 1989. Relationship between density and stiffness of apple flesh. J. Sci. Food Agr. 47:443-462. 